\title{
PERBEDAAN PENGGUNAAN INTENSITAS CAHAYA LAMPU TERHADAP HASIL TANGKAPAN BAGAN APUNG DI PERAIRAN SELAT ROSENBERG KABUPATEN MALUKU TENGGARA KEPULAUAN KEI
}

\author{
Julianus Notanubun ${ }^{1)}$ dan Wilhelmina Patty ${ }^{2)}$ \\ 1) Staf Pengajar Program Studi Teknologi Penangkapan Ikan, Politeknik \\ Perikanan Negeri Tual dan ${ }^{2)}$ Program Studi Pemanfaatan Sumberdaya Perikanan, \\ Fakultas Perikanan dan IImu Kelautan UNSRAT
}

\begin{abstract}
One of potential fishing grounds for small pelagic fish in Southeast Mollucas Regency is Rosenberg Strait waters. In this region, a study on the effect of different light intensities of floating lift net on fish catches was carried out. The analyses were done on light distribution of 4 light intensities different: Petromaks Lamp and Underwater Lamps of each 18 watt, 36 watt and 54 watt. This study showed that catches of floating lift net using different light intensities were statistically significantly different. The use of 36 watt and 54 watt underwater lamp yielded the same amount of catches but higher than that of 18 watt-underwater lamp and petromaks, both in number and species. Catches consisted of 17 species, 16 fishs and 1 mollusca. Number of species and size also varied with light intensity used. There were 13 fishs species dominated by Stolephorus indicus as much as $46.9 \mathrm{~kg}$ or $22 \%$ for petromaks catches, 14 fishs species dominated by Rastrelliger kanagurata as much as $64 \mathrm{~kg}$ (31\%) for 18 watt underwater lamp, 17 fishs species dominated by Rastrelliger kanagurata as much as $76 \mathrm{~kg} \mathrm{(28 \% )}$ for 36 watt underwater lamp, and 15 fishs species dominated by Stolephorus devisi as much as $54.8 \mathrm{~kg}(22 \%)$ for 54 watt underwater lamp, respectively. Based on the results, it is recommended that the use of light intensity in fishing operations of floating lift net should be 36 watt and 54 watt underwater lamps, due to high catches, both in number and species. Beside that, since light fishing has also caught illegal fish size, number of this fishing gear type should be controlled.
\end{abstract}

\section{Key words: Underwater Lamps, Pelagic fish, light fishing.}

\section{PENDAHULUAN}

Kabupaten Maluku Tenggara merupakan wilayah kepulauan dengan jumlah pulau seluruhnya berjumlah 119 pulau, luas daratan $4.676 \mathrm{~km}^{2}$ dan luas perairan $3.180,70 \mathrm{~km}^{2}$ menjadikan kabupaten ini mempunyai sumber perikanan yang cukup besar dengan volume produksi dari kegiatan perikanan tangkap pada tahun 2008 sebesar $67.309,33$ ton dengan hasil produksi perikanan ikan pelagis kecil sebesar 15.193,0 ton di mana 3.923,8 ton merupakan kontribusi perikanan bagan apung (DKP Kabupaten Maluku Tenggara, 2008).

Bagan merupakan salah satu alat tangkap yang terdapat di Indonesia dan mulai diperkenalkan di Indonesia sejak tahun 1950-an dan sudah mengalami banyak perubahan, mulai dari bagan tancap, bagan rakit sampai pada bagan perahu (Unar 1978). Bagan apung termasuk dalam alat tangkap yang menggunakan jaring angkat dan dioperasikan pada malam hari dengan menggunakan cahaya lampu untuk menarik ikan.

Cahaya lampu merupakan suatu bentuk alat bantu secara optik yang digunakan untuk menarik dan mengkonsentrasikan ikan. Sejak waktu lama metode ini telah diketahui secara efektif di perairan air tawar maupun di laut, untuk menangkap ikan secara individu maupun secara bergerombol. Kegunaan cahaya lampu dalam metode penangkapan ikan adalah untuk menarik ikan, serta mengkonsentrasikan dan menjaga agar ikan tetap terkonsentrasi dan mudah ditangkap.

Pemanfaatan lampu sebagai alat bantu penangkapan ikan telah berkembang secara cepat sejak ditemukan lampu listrik. Sebagian besar nelayan beranggapan bahwa semakin besar intensitas cahaya yang digunakan maka akan memperbanyak hasil 
tangkapannya sehingga tidak jarang nelayan menggunakan lampu yang relatif banyak jumlahnya dengan intensitas yang tinggi dalam operasi penangkapannya. Anggapan tersebut tidak benar, karena masing-masing ikan mempunyai respon terhadap besarnya intensitas cahaya yang berbeda-beda (Wiyono, 2006 dalam Notanubun 2010).

Studi terhadap besarnya nilai intensitas cahaya yang mampu menarik ikan pada setiap jenis ikan perlu dilakukan. Hal ini penting, selain agar ikan target tepat berada dalam area penangkapan, juga untuk menghindari pengurasan ikan tangkapan dan pemborosan biaya penangkapan. Sebab tidak jarang, dalam operasi penangkapan ikan dengan alat bantu cahaya ikan-ikan yang belum layak ditangkap (belum memijah) atau bahkan masih juvenil ikut tertangkap sebagai hasil tangkapan ikan sampingan, bila ini dilakukan terusmenerus, maka kerusakan sumberdaya ikan tinggal menunggu waktunya. (Notanubun 2010). Berdasarkan pernyataan tersebut di atas, maka penelitian ini bertujuan untuk: (1) Mengidentifikasi jenisjenis hasil tangkapan berdasarkan intensetas cahaya lampu yang berbeda, (2) Menentukan inetensitas cahaya lampu yang memberikan jumlah hasil tangkapan terbesar.

\section{METODOLOGI}

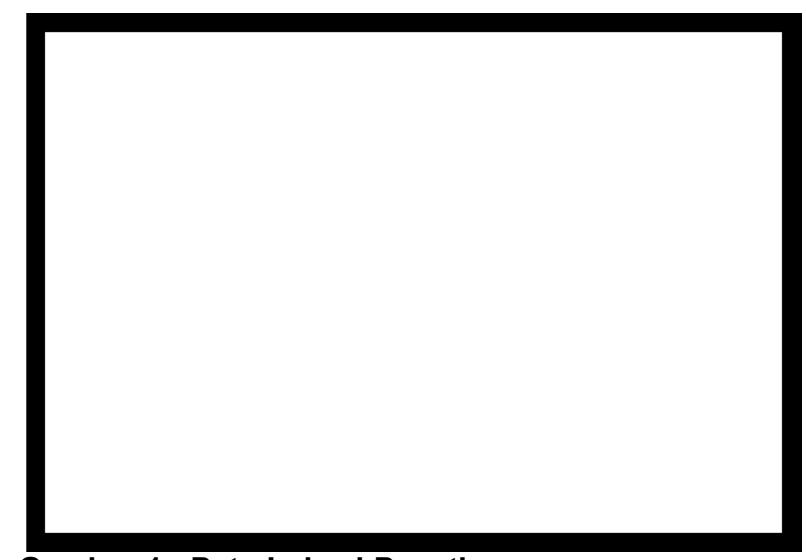

Gambar 1. Peta Lokasi Penetian

Penelitian ini dilaksanakan selama empat bulan (April-Juli 2010), yang meliputi persiapan peralatan, pengamatan, pengukuran, pengumpulan data dan analisis data. Lokasi daerah pengoperasian dan penangkapan (fishing ground) di perairan Selat
Rosenberg Kabupaten Maluku Tenggara Kepulauan Kei (Gambar 1), yang terletak pada posisi geografis antara $5^{\circ} 42^{\prime} 29,40^{\prime \prime}$ $5^{\circ} 43^{\prime} 05,49^{\prime \prime}$ LS dan $132^{\circ} 46^{\prime} 34,1^{\prime \prime}-132^{\circ} 47^{\prime}$ $31,11^{\prime \prime}$ BT.

Penelitian ini dilakukan dengan menggunakan metode percobaan yakni berupa rancangan acak kelompok (RAK), dimana menggunakan intensitas cahaya lampu yang berbeda sebagai perlakuan, yakni lampu celup bawah air 18, 36 dan 54 watt serta lampu petromaks yang dipasang pada 4 unit bagan apung secara acak selama 5 hari operasi penangkapan sebagai kelompok dengan bagan pengacakan sebagaimana terlihat pada Gambar 2.
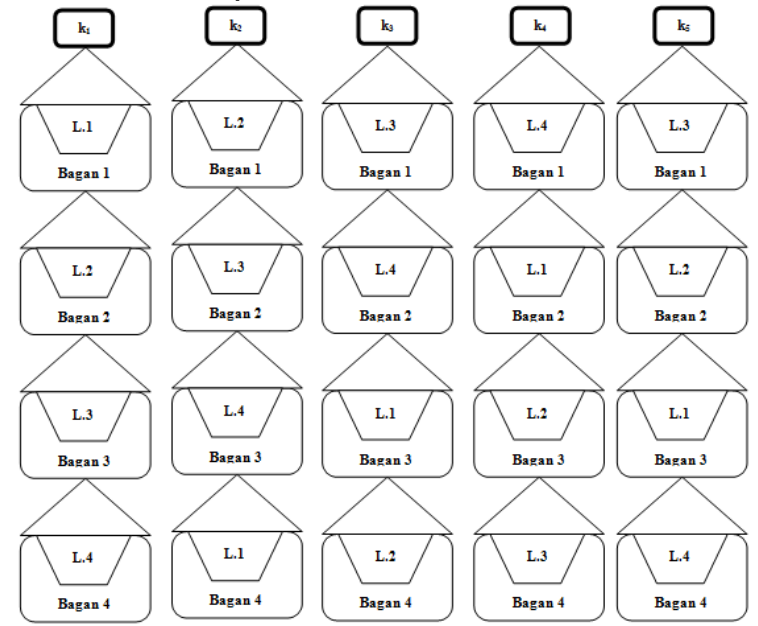

Gambar 2. Pengacakan pemasangan lampu pada bagan apung

Keterangan:

k : Hari operasi penangkapan bagan apung

L. 1 : Lampu petromaks 4 unit

L.2 : Lampu Celup Bawah Air 1 unit 18 watt

L.3 : Lampu Celup Bawah Air 2 unit 36 watt

L.4 : Lampu Celup Bawah Air 3 unit 54 watt

Pengamatan dan pengukuran data dilakukan mulai pukul 18.00-04.20 WIT bersamaan dengan dioperasikannya empat bagan apung tersebut dengan interval waktu setting hingga hauling 3 jam yaitu pertama mulai pukul 18.00-21.00 WIT, kedua pukul 21.40-00.40 WIT dan ketiga pukul 01.2014.20 WIT.

Data jumlah hasil tangkapan $(\mathrm{Kg})$ dari empat bagan apung yang digunakan ditabulasi menurut intensitas cahaya lampu dan hari operasi penangkapan. Untuk mengetahui pengaruh perbedaan besarnya intensitas cahaya lampu terhadap hasil tangkapan $(\mathrm{Kg})$ bagan apung digunakan analisis sidik ragam rancangan acak 
kelompok (RAK) (Gaspersz, 1994) dengan rumus matematis sebagai berikut:

$$
\mathrm{Y}_{\mathrm{ij}}=\mu+\alpha_{\mathrm{i}}+\beta_{\mathrm{j}}+\varepsilon_{\mathrm{ij}}
$$

dimana:

$\mathrm{i}=1,2, \ldots, \mathrm{t}_{\mathrm{i}}$ (perlakuan lampu)

$\mathrm{j}=1,2, \ldots, \mathrm{r}_{\mathrm{j}}$ (kelompok hari operasi penangkapan)

$\mathrm{Y}_{\mathrm{ij}}=$ nilai pengamatan perlakuan ke-i dalam kelompok ke-j

$\mu=$ nilai tengah (rata-rata) populasi

$\alpha_{i}=$ pengaruh dari perlakuan-i

$\beta_{\mathrm{j}}=$ pengaruh dari kelompok

$\varepsilon_{\mathrm{ij}}=$ pengaruh galat percobaan dari perlakuan ke-i pada kelompok ke-j

Model perlakuan akan diacak dengan mengikuti pola seperti pada Tabel 1.

Tabel 1. Model pengamatan untuk rancangan acak kelompok (RAK)

\begin{tabular}{|c|c|c|c|c|c|c|c|}
\hline \multirow{2}{*}{ Perlakuan } & \multicolumn{4}{|c|}{ Kelompok } & \multirow[b]{2}{*}{$\mathrm{K}_{5}$} & \multirow{2}{*}{$\begin{array}{c}\text { Total } \\
\text { Perlakuan }\end{array}$} & \multirow{2}{*}{$\begin{array}{l}\text { Rata- } \\
\text { rata }\end{array}$} \\
\hline & $\mathrm{K}_{1}$ & $\mathrm{~K}_{2}$ & $\mathrm{~K}_{3}$ & $\mathrm{~K}_{4}$ & & & \\
\hline $\mathrm{L}_{1}$ & $\mathrm{~B}_{1} \mathrm{~L}_{1}$ & $\mathrm{~B}_{4} \mathrm{~L}_{1}$ & $\mathrm{~B}_{3} \mathrm{~L}_{1}$ & $\mathrm{~B}_{2} \mathrm{~L}_{1}$ & $\mathrm{~B}_{3} \mathrm{~L}_{1}$ & $\mathrm{~T}_{1}$ & $\ddot{y}_{1}$ \\
\hline $\mathrm{L}_{2}$ & $\mathrm{~B}_{1} \mathrm{~L}_{2}$ & $\mathrm{~B}_{2} \mathrm{~L}_{2}$ & $\mathrm{~B}_{4} \mathrm{~L}_{2}$ & $\mathrm{~B}_{3} \mathrm{~L}_{2}$ & $\mathrm{~B}_{2} \mathrm{~L}_{2}$ & $\mathrm{~T}_{2}$ & $\ddot{y}_{2}$ \\
\hline $\mathrm{L}_{3}$ & $\mathrm{~B}_{3} \mathrm{~L}_{3}$ & $\mathrm{~B}_{2} \mathrm{~L}_{3}$ & $\mathrm{~B}_{1} \mathrm{~L}_{3}$ & $\mathrm{~B}_{4} \mathrm{~L}_{3}$ & $\mathrm{~B}_{1} \mathrm{~L}_{3}$ & $\mathrm{~T}_{3}$ & $\ddot{y}_{3}$ \\
\hline $\mathrm{L}_{4}$ & $\mathrm{~B}_{4} \mathrm{~L}_{4}$ & $\mathrm{~B}_{3} \mathrm{~L}_{4}$ & $\mathrm{~B}_{2} \mathrm{~L}_{1}$ & $B_{1} L_{1}$ & $\mathrm{~B}_{4} \mathrm{~L}_{4}$ & $\mathrm{~T}_{4}$ & $\ddot{y}_{4}$ \\
\hline Total Kelompok & $\mathrm{T}_{.1}$ & $\mathrm{~T}_{.2}$ & $\mathrm{~T} .3$ & $\mathrm{~T}_{4}$ & $\mathrm{~T}_{5}$ & $T$ & \\
\hline Rata-rata & $\ddot{y}_{1}$ & $\ddot{y}_{2}$ & $\ddot{y}_{3}$ & $\ddot{y}_{4}$ & $\ddot{y}_{5}$ & & $\ddot{y}$ \\
\hline
\end{tabular}

Setelah data dimasukkan dalam Tabel 1, kemudian dilanjutkan dengan analisis sidik ragam dengan menggunakan model seperti pada Tabel 2.

Tabel 2. Model analiss sidik ragam untuk rancangan acak kelompok (RAK)

\begin{tabular}{lcccc}
\hline Sumber Keragaman & $\mathrm{db}$ & JK & KT & F hit \\
\hline Kelompok & $\mathrm{k}-1$ & JKK & KTK & KTK/KTG \\
Perlakuan & $\mathrm{t}-1$ & JKP & KTP & KTP/KTG \\
Galat & $(\mathrm{r}-1)(\mathrm{t}-1)$ & JKG & KTG & \\
Total & $\mathrm{kt}-1$ & JKT & & \\
\hline
\end{tabular}

Jika hasil uji sidik ragam menunjukkan bahwa terdapat pengaruh yang nyata dalam perbedaan penggunaan intensitas lampu terhadap hasil tangkapan bagan apung, maka dilakukan uji Beda Nyata Terkecil (BNT) untuk melihat perlakuan yang paling berpengaruh terhadap hasil tangkapan dengan menggunakan rumus:

$$
\text { BNT }_{\alpha}=\mathrm{t}_{\alpha}\left(\frac{2 \mathrm{~S}^{2}}{\mathrm{r}}\right)^{\frac{1}{2}}
$$

dimana:

BNTa : beda nyata terkecil pada tingkat kepercayaan $\alpha$

ta : derajat bebas galat (diperoleh pada tabel analisis sidik ragam)

s2 : nilai KTG yang diperoleh dari analisis sidik ragam

: jumlah ulangan/kelompok

Hipotesis yang diajukan dalam penelitian ini, yaitu:
$\mathrm{H}_{0}=$ Perbedaan pengunaan intensitas cahaya lampu pada bagan apung tidak memberikan pengaruh yang nyata terhadap hasil tangkapan $(\mathrm{Kg})$

$\mathrm{H}_{1}=$ Perbedaan pengunaan intensitas cahaya lampu pada bagan apung memberikan pengaruh yang nyata terhadap hasil tangkapan $(\mathrm{Kg})$.

Hipotesis tersebut di atas diuji dengan menggunakan uji $F$ pada tabel analisis sidik ragam dengan kaidah keputusan sebagai berikut:

1. Jika $F_{\text {hitung }}<F_{\text {tabel }}$ maka secara statistik $\mathrm{H}_{0}$ diterima dan $\mathrm{H}_{1}$ ditolak, berarti tidak ada pengaruh yang nyata dalam penggunaan intensitas cahaya lampu yang berbeda terhadap hasil tangkapan bagan apung;

2. Jika $F_{\text {hitung }}>F_{\text {tabel }}$, maka secara statistik $\mathrm{H}_{1}$ diterima $\mathrm{H}_{0}$ ditolak, berarti ada pengaruh yang nyata dalam penggunaan intensitas cahaya lampu yang berbeda terhadap hasil tangkapan bagan apung.

Penelitian ini dilaksanakan dengan asumsi-asumsi dasar bahwa:

1. Komponen dan ukuran alat tangkap bagan apung yang digunakan serta ketrampilan nelayan dalam mengoperasikannya relatif sama;

2. Tingkat ketelitian dalam pengamatan dan pengukuran data relatif sama;

3. Penyebaran ikan merata di perairan lokasi penelitian sepanjang malam sehingga memberikan peluang yang sama untuk tertangkap.

\section{HASIL DAN PEMBAHASAN}

\section{Jenis Hasil Tangkapan}

Hasil penelitian dengan menggunakan 4 unit alat tangkap bagan apung diperoleh 16 jenis ikan dan 1 jenis moluska yaitu Loligo sp (Tabel 3). Umumnya, jenis-jenis ikan yang tertangkap ini adalah ikan pelagis kecil dan ada beberapa jenis ikan demersal. Dari 17 jenis hasil tangkapan terdapat 5 jenis yang mendominasi hasil tangkapan selama operasi penangkapan yaitu jenis Rastrelliger kanagurta dengan berat total $215,7 \mathrm{Kg}(22,7 \%)$, Stolephorus devisi 139.3 $\mathrm{Kg}(14,7 \%)$, Stolephorus indicus $102,2 \mathrm{Kg}$ $(10,8 \%)$ Selar crumenophthalmus $88,8 \mathrm{Kg}$ $(9,4 \%)$ dan Stolephorus heterolobus 80,8 
Intensitas Cahaya Lampu di Bagan Apung

$\mathrm{Kg}(7,8 \%)$. Jenis-jenis hasil tangkapan menurut intensitas cahaya lampu dapat dilihat pada Tabel 4.

Tabel 3. Hasil tangkapan menurut jenis dan berat selama penelitian

\begin{tabular}{|c|c|c|c|c|c|}
\hline \multirow[b]{2}{*}{ No } & \multirow{2}{*}{ Famili } & \multicolumn{2}{|r|}{ Nama Jenis } & \multirow{2}{*}{$\begin{array}{l}\text { Berat Total } \\
(\mathrm{Kg})\end{array}$} & \multirow{2}{*}{$\%$} \\
\hline & & Umum & IImiah & & \\
\hline 1 & Scombridae & Mackerel & Rastrelliger kanagurta & 215,7 & 22,7 \\
\hline 2 & Engraulididae & Teri & Stolephorus devisi & 139,3 & 14,7 \\
\hline 3 & Engraulididae & Teri & Stolephorus indicus & 102,2 & 10,8 \\
\hline 4 & Carangidae & Kawalina & Selar crumenophthalmus & 88,8 & 9,4 \\
\hline 5 & Engraulididae & Teri & Stolephorus heterolobus & 80,8 & 8,5 \\
\hline 6 & Anterinadae & Teri & Atherion elimus & 61,1 & 6,9 \\
\hline 7 & Sphyraenidae & Alu-alu & Spyraena baracuda & 60,5 & 6,0 \\
\hline 8 & Carangidae & Pale & Selar boops & 59,1 & 6,2 \\
\hline 9 & Clupedae & Sardin & Sardinella gibson & 49,9 & 5,3 \\
\hline 10 & Echenedidae & Layang & Decapterus macrosoma & 39,0 & 4,1 \\
\hline 11 & Lutjanidae & Pisang-pisang & Pteracaesi pisang & 33,5 & 3,5 \\
\hline 12 & Belonidae & Sako & Tylosorus acus meranotus & 8,9 & 0,9 \\
\hline 13 & Ambossidae & Gete-gete & Ambossis urataeni & 4,4 & 0,5 \\
\hline 14 & Carangidae & Bobara & Caranx sexfaciatus & 2,9 & 0,3 \\
\hline 15 & Loliginidae & Cumi & Loligo sp & 1,6 & 0,2 \\
\hline 16 & Priacanthidae & Mata besar & Priacanthus hamrur & 0,8 & 0,1 \\
\hline \multirow[t]{2}{*}{17} & Lutjanidae & Gurara & Lutjanus bigutatus & 0,3 & 0,03 \\
\hline & & & Berat total $(\mathrm{Kg})$ & 948,7 & 100,0 \\
\hline
\end{tabular}

Tabel 4. Distribusi jenis hasil tangkapan menurut intensitas cahaya lampu yang digunakan

\begin{tabular}{|c|c|c|c|c|c|}
\hline \multirow[b]{2}{*}{ Jenis Ikan } & \multicolumn{4}{|c|}{ Intensitas Cahaya yang digunakan } & \multirow[b]{2}{*}{ Jumlah } \\
\hline & $\begin{array}{l}\text { Lampu } \\
\text { Petromaks }\end{array}$ & $\begin{array}{c}\text { Lampu Celup } \\
\text { Bawah Air } \\
18 \text { watt }\end{array}$ & $\begin{array}{c}\text { Lampu Celup } \\
\text { Bawah Air } \\
36 \text { watt }\end{array}$ & $\begin{array}{c}\text { Lampu Celup } \\
\text { Bawah Air } \\
54 \text { watt }\end{array}$ & \\
\hline Rastrelliger kanagurta & + & + & + & + & 4 \\
\hline Stolephorus devisi & + & + & + & + & 4 \\
\hline Stolephorus indicus & + & + & + & + & 4 \\
\hline Selar crumenophthalmus & + & + & + & + & 4 \\
\hline Stolephorus heterolobus & + & + & + & + & 4 \\
\hline $\begin{array}{l}\text { Atherion elimus } \\
\text {. }\end{array}$ & + & + & + & + & 4 \\
\hline Spyraena baracuda & + & + & + & + & 4 \\
\hline Selar boops & + & + & + & + & 4 \\
\hline Sardinella gibson & + & + & + & + & 4 \\
\hline Decapterus macrosoma & + & + & + & + & 4 \\
\hline Pteracaesipisang & + & + & + & + & 4 \\
\hline Tylosorus acus meranotus & + & + & + & + & 4 \\
\hline Ambossis urataeni & - & + & + & + & 3 \\
\hline Caranx sexfaciatus & . & . & + & + & 2 \\
\hline Loligo sp & + & + & + & + & 4 \\
\hline Priacanthus hamrur & & - & + & - & 1 \\
\hline Lutjanus bigutatus & & & + & & 1 \\
\hline Jumlah jenis & 13 & 14 & 17 & 15 & \\
\hline
\end{tabular}

Dari Tabel 4 terlihat bahwa lampu celup bawah air 36 watt menangkap jumlah jenis lebih banyak yakni 17 jenis (100\%) diikuti lampu celup bawah air 54 dengan 15 jenis $(88,2 \%)$ kemudian lampu celup bawah air 18 watt 14 jenis $(82,3 \%)$ dan lampu petromaks 13 jenis $(76,5 \%)$, hal ini menunjukkan bahwa intensitas cahaya lampu yang tinggi lebih mampu menarik jenis ikan lebih banyak ke sumber cahaya. Hal ini mengakibatkan keberadaan ikan tidak hanya di sekitar bagan tapi juga di bawah bagan. Namun demikian menurut Yami (1988), ikan selalu menjaga jarak dengan sumber cahaya, karena ikan memiliki batas toleransi terhadap cahaya, sehingga demikian maka walaupun lampu celup bawah air 54 watt memiliki intensitas cahaya yang tinggi namun jumlah jenis hasil tangkapan sedikit bila dibandingkan dengan lampu celup bawah air 36 watt.

Selanjutnya dijelaskan pula bahwa intensitas cahaya yang tinggi dari lampu celup bawah air 54 dan 36 watt mampu menarik banyak ikan fototaksis positif untuk datang. Ini berimplikasi pada banyaknya ikan-ikan predator yang datang berkumpul di sekitar bagan. Meskipun ikan predator tidak tertarik pada cahaya, tapi ikan mencari makan dengan tetap memanfaatkan indera penglihatan (Causteau 2003), sehingga terlihat dari jenis hasil tangkapan yang menunjukkan bahwa intensitas cahaya lampu celup bawah air 54 dan 36 watt menangkap jenis ikan Caranx sexfaciatus yang tidak ditemukan pada lampu Petromaks dan lampu celup bawah air 18 watt, serta menangkap jenis ikan predator seperti Spyraena baracuda dan Tylosorus acus meranotus lebih banyak bila dibandingkan dengan lampu petromaks dan lampu celup bawah air 18 Watt.

\section{Jumlah Hasil Tangkapan Menurut Perlakuan Lampu}

Hasil tangkapan berdasarkan perlakuan cahaya lampu menunjukkan bahwa jumlah ikan yang tertangkap pada bagan apung dengan cahaya lampu celup bawah air 36 watt dan 54 watt relatif lebih banyak yakni untuk lampu celup bawah air 36 watt dengan berat total $274,3 \mathrm{~kg}(28,91 \%)$, lampu celup bawah air 54 watt $255,2 \mathrm{~kg}$ $(26,90 \%)$ bila dibandingkan lampu Petromaks dan lampu celup bawah air 18 watt (Tabel 5 dan Gambar 3).

Tabel 5. Sebaran Jumlah Hasil tangkapan bagan apung menurut intensitas cahaya lampu
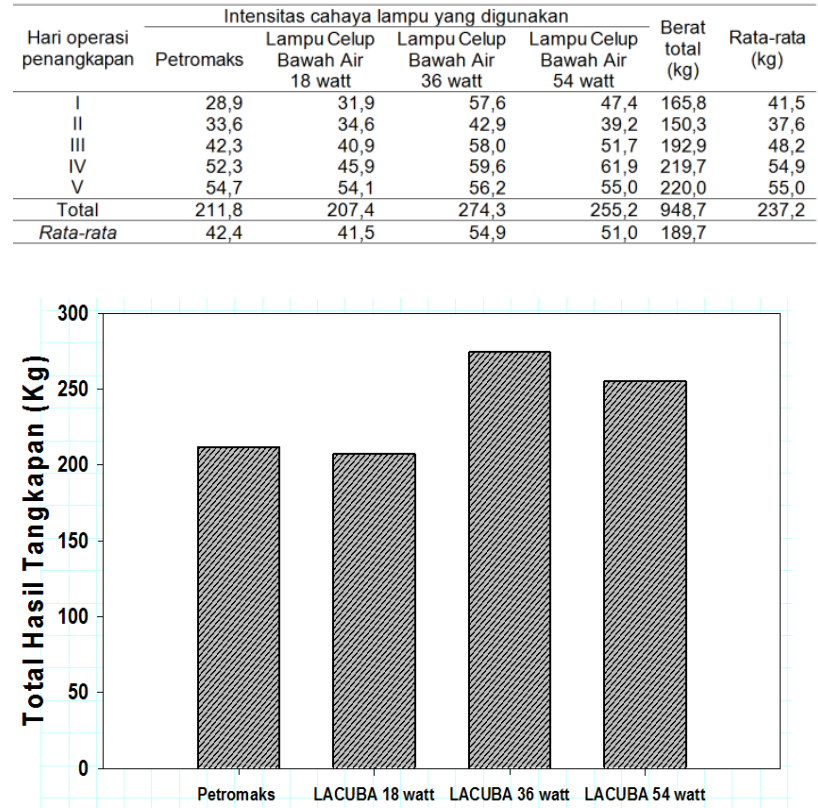

Perlakuan Lampu 
Gambar 3. Jumlah hasil tangkapan (kg) menurut perlakuan intensitas cahaya

Hasil analisis sidik ragam (Tabel 6) menunjukkan bahwa nilai $F_{\text {hit }}$ perlakuan $(6,230)$ lebih besar dari nilai $F_{\text {tab }}(0,05)$; $(12: 3)(3,59)$ sehingga secara statistik $H_{0}$ ditolak. Hal ini berarti bahwa perbedaan penggunaan intensitas cahaya pada bagan apung berpengaruh sangat nyata pada tingkat ó=0,01 dan 0,05 terhadap hasil tangkapan. Hasil analisis uji lanjut dengan BNT menunjukkan bahwa hasil tangkapan dengan menggunakan perlakuan intensitas cahaya lampu petromaks tidak berbeda nyata dengan lampu celup bawah air 18 Watt, tapi berbeda dengan lampu celup bawah air 36 dan 54 watt (Tabel 7).

Tabel 6. Hasil analisis sidik ragam hasil tangkapan bagan apung berdasarkan perlakuan intensitas cahaya

\begin{tabular}{|c|c|c|c|c|c|c|}
\hline \multirow{2}{*}{$\begin{array}{l}\text { Sumber } \\
\text { Keragaman }\end{array}$} & \multirow{2}{*}{$\begin{array}{c}\text { Derat } \\
\text { bebas } \\
(\mathrm{db})\end{array}$} & \multirow{2}{*}{$\begin{array}{l}\text { Jumlah } \\
\text { Kuadrat } \\
\text { (JK) }\end{array}$} & \multirow{2}{*}{$\begin{array}{l}\text { Kuadrat } \\
\text { Tengah } \\
\text { (KT) }\end{array}$} & \multirow[b]{2}{*}{$\mathrm{F}_{\text {nit }}$} & \multicolumn{2}{|c|}{$F_{\text {tab }}$} \\
\hline & & & & & 0,05 & 0,01 \\
\hline Perlakuan & 3 & 646,722 & 161,680 & $6,230^{\star \star}$ & 3,59 & 5,95 \\
\hline Kelompok & 4 & 987,973 & 329,324 & $12,689^{\star \star}$ & 3,26 & 5,41 \\
\hline Galat & 12 & 311,431 & 25,953 & - & - & - \\
\hline Total & 19 & 1946,126 & - & - & - & - \\
\hline
\end{tabular}

Tabel 7. Hasil uji BNT rata-rata hasil tangkapan berdasarkan perlakuan intensitas cahaya lampu

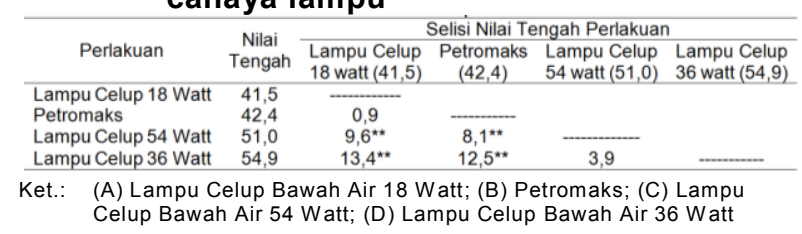

Berdasarkan hasil analisis menunjukkan bahwa hasil tangkapan dapat ditingkatkan jika menggunakan lampu celup bawah air dengan intensitas 36 atau 54 watt. Sejalan dengan hasil penelitian yang telah dilakukan oleh Najamuddin dan Assir (1993) menunjukkan bahwa hasil yang diperoleh dengan menggunakan lampu neon dalam air nyata jauh lebih baik dari pada lampu petromaks dan dari segi finansialnya ditemukan bahwa penggunaan lampu neon dalam air membutuhkan biaya operasional alat bantu hampir $1 / 20$ (seperduapuluh) dari penggunaan lampu petromaks. Sementara pendapatan pada lampu neon ternyata juga hampir dua kali lipat dari hasil yang diperoleh pada penggunaan lampu petromaks. Hal ini juga sejalan dengan pernyataan Subani (1983) bahwa sumber cahaya (lampu) yang ditempatkan dalam air akan memberikan hasil tangkapan yang lebih baik di- bandingkan jika ditempatkan di atas permukaan air. Selanjutnya menurut Yami (1987), lampu dalam air memiliki beberapa keunggulan seperti lampu yang diperlukan untuk mengumpulkan ikan lebih sedikit, hampir semua cahaya dapat digunakan, serta ikan yang sudah terkumpul jarang terserak lagi.

Berdasarkan hasil yang diperoleh maka dapat dijelaskan pula bahwa lampu celup bawah air 36 watt memperoleh hasil tangkapan terbesar. Hal ini disebabkan karena intensitas cahaya yang dihasilkan lampu celup bawah air 36 watt mampu menarik ikan lebih banyak masuk dalam areal penangkapan dan ikan beradaptasi secara sempurna pada saat hauling jika dibandingkan dengan lampu petromaks dan lampu celup bawah air 18 watt intensitas cahaya bawah air yang dihasilkan kecil sehingga kurang mampu untuk menarik ikan dari jarak yang jauh. Sedangkan lampu celup bawah air 54 watt intensitas cahayanya besar serta jangkauan jauh dan mampu menarik ikan lebih banyak di sekitar bagan. Namun memerlukan waktu yang lebih lama untuk ikan beradaptasi secara sempurna masuk di areal penangkapan. Hal ini sejalan dengan apa yang dinyatakan oleh Puspito (2008) bahwa ikan memiliki batas toleransi yang berbeda-beda terhadap cahaya. Cahaya yang terlalu kuat akan membuat ikan bergerak menjauh sampai batas toleransi yang tepat. Selanjutnya menurut Yami (1988) bahwa ikan selalu menjaga jarak dengan sumber cahaya, karena ikan memiliki batas toleransi terhadap cahaya. Dinyatakan pula bahwa tingkah laku ikan pada malam terhadap cahaya buatan akan memberikan reaksi yang sama seperti pada cahaya alami yang intensitasnya sesuai dengan batas toleransinya. Dengan demikian maka cahaya buatan yang berintensitas kuat akan menarik ikan untuk mendekat, tapi ikan akan tetap menjaga jarak dengan sumber cahaya tersebut. Selanjutnya dijelaskan pula bahwa intensitas cahaya yang rendah dari lampu petromaks dan lampu celup bawah air 18 watt selain kemampuan mengumpulkan ikan sedikit juga menyebabkan gerombolan ikan tidak bertahan lama di bawah bagan jika dibandingkan dengan intensitas cahaya lampu celup bawah air 36 watt dan 54 watt. Menurut Puspito (2008) cahaya berintensitas rendah akan membuat ikan 
Intensitas Cahaya Lampu di Bagan Apung

menjadi lebih mendekat ke sumber cahaya. Namun permasalahannya adalah jumlah ikan yang mendekat sangat sedikit.

\section{Jumlah Hasil Tangkapan Berdasarkan Hari Operasi Penangkapan}

Hasil tangkapan dengan bagan apung selama penelitian ternyata juga bervariasi menurut hari operasi penangkapan (Tabel 8). Hasil tangkapan ikan pada hari V dan IV lebih tinggi dari ke 3 hari sebelumnya, yakni berturut turut $220 \mathrm{~kg}$ dan 219,7 $\mathrm{Kg}$. Terutama pada hari II, jumlah hasil tangkapan hanya mencapai $150,3 \mathrm{Kg}(16 \%)$ dari berat total hasil tangkapan.

Tabel 8. Sebaran hasil tangkapan bagan apung berdasarkan hari operasi penangkapan

\begin{tabular}{cccc}
\hline $\begin{array}{c}\text { Kelompok } \\
\text { Hari Operasi }\end{array}$ & $\begin{array}{c}\text { Waktu } \\
\text { Penangkapan }\end{array}$ & Berat Total (Kg) & Rata-rata (Kg) \\
\hline I & Sabtu 8 Mei 2010 & 165,8 & 41,5 \\
II & Senin 10 Mei 2010 & 150,3 & 37,6 \\
III & Selasa 11 Mei 2010 & 192,9 & 48.2 \\
IV & Sabtu 15 Mei 2010 & 219,7 & 54,9 \\
V & Sabtu 22 Mei 2010 & 220,0 & 55,0 \\
\hline \multicolumn{4}{c}{} \\
\hline
\end{tabular}

Setelah dilakukan uji Beda Nyata Terkecil (BNT) untuk kelompok hari operasi penangkapan (Tabel 9) menunjukkan bahwa ada perbedaan yang nyata antara kelompok hari IV dan V dengan hari I dan II, sedangkan hari III hanya berbeda nyata dengan hari II.

Tabel 9. Hasil uji BNT rata-rata hasil tangkapan berdasarkan kelompok hari operasi

\begin{tabular}{|c|c|c|c|c|c|c|}
\hline \multirow{2}{*}{$\begin{array}{c}\text { Kelompok } \\
\text { Hari } \\
\text { Operasi }\end{array}$} & \multirow[b]{2}{*}{$\begin{array}{c}\text { Nilai } \\
\text { Tengah }\end{array}$} & \multicolumn{5}{|c|}{ Selisih Nilai Tengah Kelompok } \\
\hline & & II $(37,6)$ & I $(41,5)$ & III $(48,2)$ & IV $(54,9)$ & $V(55)$ \\
\hline II & 37,6 & - & & & & \\
\hline I & 41,5 & 3,9 & ----"- & & & \\
\hline III & 48,2 & $10,3^{* \star}$ & 6,8 & & & \\
\hline IV & 54,9 & $17,4^{\star \star}$ & $13,5^{\star \star}$ & 6,7 & & \\
\hline V & 55 & $17,4^{\star \star}$ & $13,6^{\star \star}$ & 6,8 & 0,1 & -..-- \\
\hline
\end{tabular}

$\left.{ }^{\star \star *}\right)$ Berbeda nyata pada taraf $\alpha=0,05$

Perbedaan jumlah hasil tangkapan diantara kelima hari operasi tersebut kemungkinan disebabkan oleh faktor lingkungan yakni arus dan salinitas, dimana kecepatan arus yang diukur pada hari ke 4 dan 5 relatif lebih besar yakni 0,216-0,367 $\mathrm{m} /$ det. Lokasi penelitian adalah daerah selat yang relatif sempit sehingga keberadaan arus permukaan yang kuat dapat mengaduk masa air dan menyebabkan daerah itu kaya akan nutrient. Hal ini berpengaruh tidak langsung terhadap kelimpahan ikan. Seperti yang ditulis oleh Nybakken (1992) bahwa pergerakan air yang cukup kuat di permukaan menimbulkan terjadi pergerakan masa air atau percampuran masa air dan secara tidak langsung akan mempengaruhi kelimpahan makanan dan ikan di daerah tersebut. Ditambahkan oleh Baskoro $d k k$. (2004) bahwa arus permukaan berpengaruh terhadap transportasi juvenil sehingga mempengaruhi migrasi ikan ke lokasi penangkapan. Selanjutnya menurut (Reddy, 1993) bahwa ikan bereaksi secara langsung terhadap perubahan lingkungan yang dipengaruhi oleh arus dengan mengarahkan dirinya secara langsung pada arus dan umumnya gerakan ikan selalu mengarah menuju arus.

Salinitas yang diukur pada hari I dan II, relatif lebih tinggi yakni 32-33 ppm, karena tidak ada pengaruh air tawar (hujan) yang masuk ke perairan. Tidak semua jenis ikan dapat menyesuaikan diri dengan kondisi perairan yang demikian (Notanubun 2010). Menurut Reddy (1993) menyatakan bahwa salinitas merupakan faktor penting yang mempengaruhi keberhasilan reproduksi beberapa jenis ikan dan distribusi berbagai stadia hidup. Selanjutnya menurut Nontji (1997) dinyatakan bahwa ada ikan yang memiliki toleransi yang tinggi terhadap perubahan salinitas dan ada pula yang tidak mampu beradaptasi, dengan perubahan salinitas yang hanya sedikit, ikan biasanya tidak stabil lagi.

Selanjutnya dapat dijelaskan pula bahwa rata-rata jumlah hasil tangkapan lampu celup bawah air 36 dan 54 watt lebih tinggi untuk setiap hari operasi penangkapan jika dibandingkan dengan lampu celup bawah air 18 watt dan lampu petromaks, dengan rata-rata berat hasil tangkapan yakni: lampu celup bawah air 36 watt sebanyak $54,9 \mathrm{Kg}$, Lacuba 54 watt $51,0 \mathrm{Kg}$, sedangkan Lacuba 18 watt $41,5 \mathrm{Kg}$ dan lampu petromaks 44,4 Kg (Gambar 4).

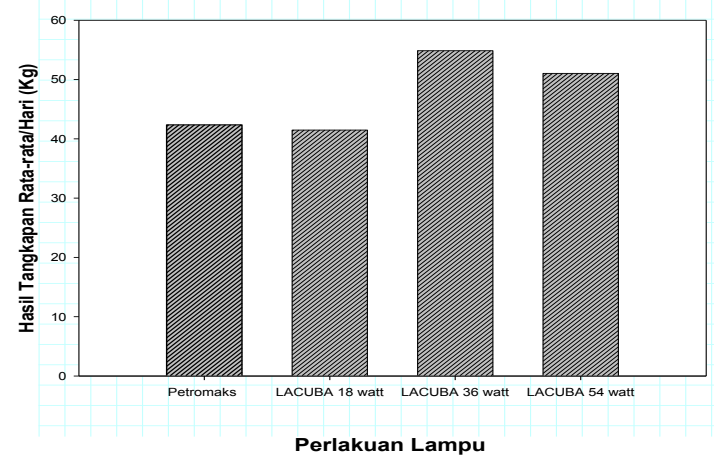


Gambar 4. Hasil tangkapan rata-rata per hari menurut perlakuan lampu

\section{KESIMPULAN}

Jenis-jenis hasil tertangkap bagan apung yang diperoleh selama penelitian umumnya jenis-jenis ikan pelagis kecil fototaksis positif yang tertarik pada cahaya, namun demikian hasil tangkapan tertinggi ditemukan pada intensitas cahaya lampu celup bawah air 36 watt dengan berat total $247,3 \mathrm{Kg}$, diikuti lampu celup bawah air 54 watt dengan berat total $255,2 \mathrm{Kg}$, lampu petromaks $211,8 \mathrm{Kg}$ dan lampu celup bawah air 18 watt $207,4 \mathrm{Kg}$. Hasil analisis menunjukan bahwa intensitas cahaya lampu celup bawah air 36 dan 54 watt tidak berbeda nyata, namun demikian perlakuan intensitas cahaya lampu celup bawah air 36 watt yang terbaik.

\section{DAFTAR PUSTAKA}

Baskoro, M.S., R.I Wahyu, dan A. Effendy. 2004. Migrasi dan Distribusi Ikan ISBN 979-96923-9-3. Institut Pertanian Bogor Departemen Pendidikan Nasional dan Sekolah Tinggi Perikanan Jakarta Departemen Kelautan dan Perikanan

Caosteau. F. 2003. Ocean Environments. London WC2R : Darling Kindersley Lied 80 Stand.

Gaspersz, V. 1994. Metode Perancangan Percobaan (Untuk IImu-IImu Pertanian, IImuIlmu Teknik dan Biologi) CV Armico Bandung.
Najamuddin dan A. Assir. 1993. Studi Penggunaan Lampu Neon dalam Air dengan Daya yang Berbeda pada Perikanan Purse Seine di Laut Flores, Sulawesi Selatan. Buletin Torani 3 (3): 74-88

Nontji, A. 1997. Laut Nusantara. Penerbit Djambatan Jakarta 368 hal.

Nybakken, J.W. 1992. Biologi Laut. Suatu Pendekatan Ekologis. Gramedia Pustaka Utama. 459 hal

Notanubun, J. 2010. Kajian Hasil Tangkapan Bagan Apung Dengan Penggunaan Intensitas Cahaya Lampu yang Berbeda di Perairan Selat Rosenberg Kabupaten Maluku Tenggara Kepulauan Kei. Tesis. Program Pascasarjana Universitas Sam Ratulangi-Manado 2010

Puspito, G. 2008. Lampu Petromaks; Manfaat, Kelemahan dan Solusinya pada Perikanan Bagan. ISBN 978-979-1225-04-5. Depatemen Pemanfaatan Sumberdaya Perikanan. Fakultas Perikanan dan KelautanIPB.2008.

Reddy, M.P.M. 1993. Influence of the Various Oceanographic Parameters on the Abundance of Fish Catch. Proceeding of International workshop on Apllication of Satellite Remote Sensing for Identifying and Forecasting Potential Fishing Zones in Developing Countries, India, 7-11 December 1993.

Subani. W. 1983. Penggunaan Lampu Sebagai Alat Bantu Penangkapan Ikan. Laporan Penelitian Perikanan Laut. 27:45-48

Yami. B. 1988. Attracting Fish with Light. Roma : FAO 